\title{
Visual categorisation of the Arch Index: a simplified measure of foot posture in older people
}

Hylton B Menz*, Mohammad R Fotoohabadi, Elin Wee, Martin J Spink

From 3rd Congress of the International Foot and Ankle Biomechanics Community

Sydney, Australia. 11-13 April 2012

\section{Background}

Many foot posture measurement approaches are not suitable for routine use as they are time-consuming or require specialised equipment and/or clinical expertise. The objective of this study was to develop and evaluate a simple visual assessment tool for foot posture assessment based on the Arch Index (AI) [1].

\section{Materials and methods}

Fully weightbearing footprints from 602 people aged 62 to 96 years were obtained using a carbon paper imprint material, and cut-off AI scores dividing participants into three categories (high, normal and low) were determined. A visual tool was created using representative examples for the boundaries of each category (Figure 1). Two

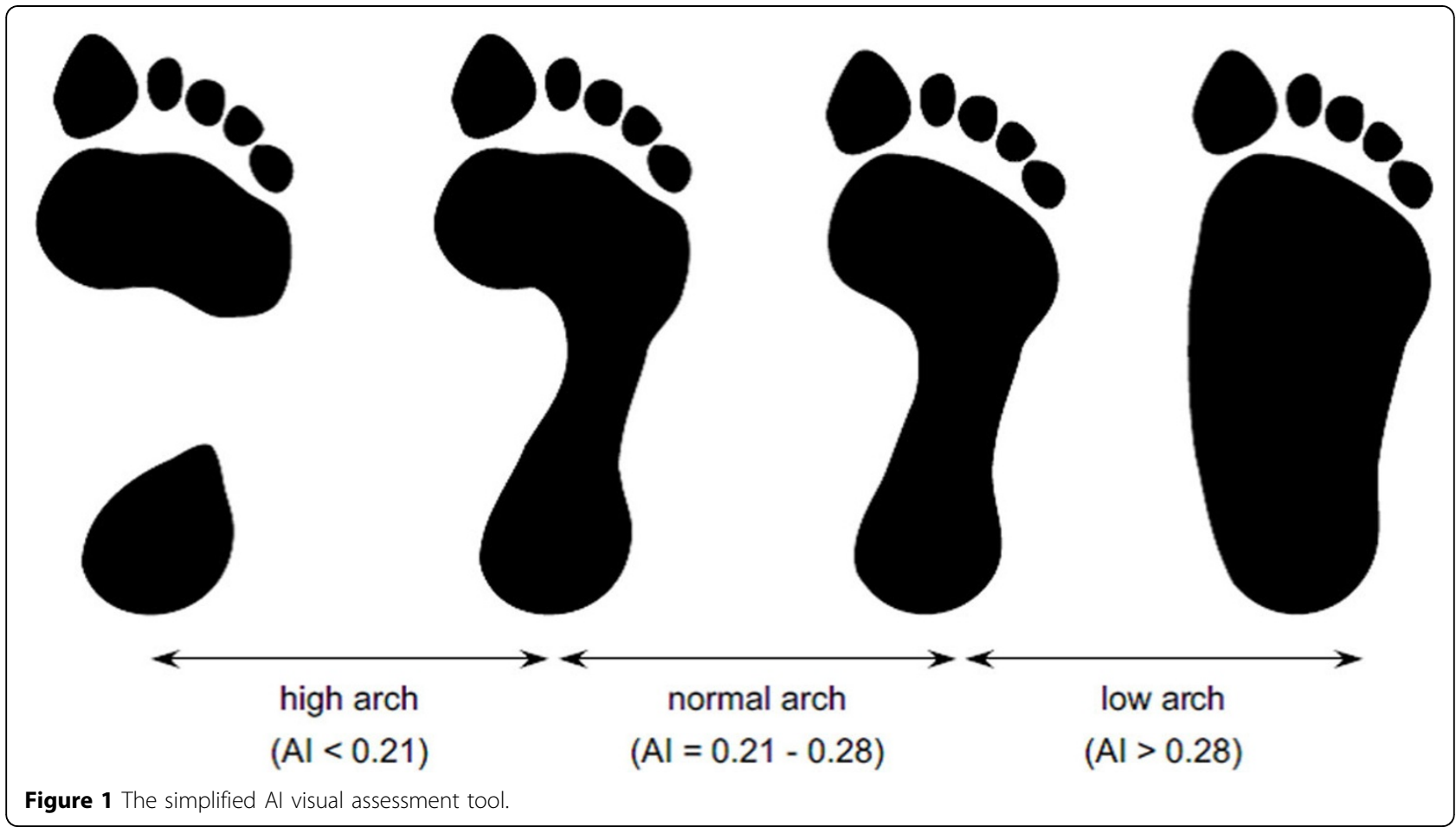

* Correspondence: h.menz@latrobe.edu.au

Musculoskeletal Research Centre, La Trobe University, Bundoora, Victoria 3086, Australia

(c) 2012 Menz et al; licensee BioMed Central Ltd. This is an Open Access article distributed under the terms of the Creative Commons 
examiners used the tool to independently grade the footprints of 60 participants ( 20 for each of the three categories, randomly presented), and then repeat the process two weeks later. Inter- and intra-tester reliability were determined and the validity of the examiner's assessments was evaluated by comparing their categorisations to the actual AI score.

\section{Results}

Inter- and intra-tester reliability of the examiners was almost perfect (percentage agreement $=93$ to 97\%; Spearman's rho $=0.91$ to 0.95 , and weighted kappas = 0.85 to 0.93$)$. Examiner's scores were strongly correlated with actual AI values (Spearman's rho $=0.91$ to 0.94 and significant differences between all categories with ANOVA; $<<0.001$ ) and AI categories (percentage agreement $=95$ to $98 \%$; Spearman's rho $=0.89$ to 0.94 , and weighted kappas $=0.87$ to 0.94 ). There was a slight tendency for examiners to categorise participants as having higher arches than their AI scores indicated.

\section{Conclusions}

Foot posture can be quickly and reliably categorised as high, normal or low in older people using a simplified visual categorisation tool based on the AI.

Published: 10 April 2012

\section{Reference}

1. Cavanagh PR, Rodgers MM: The arch index: a useful measure from footprints. J Biomech 1987, 20:547-551.

doi:10.1186/1757-1146-5-S1-P15

Cite this article as: Menz et al:: Visual categorisation of the Arch Index: a simplified measure of foot posture in older people. Journal of Foot and Ankle Research 2012 5(Suppl 1):P15.
Submit your next manuscript to BioMed Central and take full advantage of:

- Convenient online submission

- Thorough peer review

- No space constraints or color figure charges

- Immediate publication on acceptance

- Inclusion in PubMed, CAS, Scopus and Google Scholar

- Research which is freely available for redistribution

Submit your manuscript at www.biomedcentral.com/submit 